\title{
ИЗМЕНЕНИЕ ТВЕРДЫХ ТКАНЕЙ ЗУБОВ У ДЕТЕЙ ДО 3 ЛЕТ, ПЕРЕНЕСШИХ ГИПОКСИЮ ПЛОДА ВНУТРИУТРОБНО
}

\section{CHANGES IN THE HARD TISSUES \\ OF TEETH IN CHILDREN UNDER3 YEARS \\ OF AGE WHO UNDERWENT FETAL HYPOXIA IN UTERO}

O. Makarchuk
S. Gromova

Summary. Intrauterine fetal hypoxia is quite common, which can be both acute and chronic condition. The causes of hypoxia are quite extensive. In turn, this state of the fetus affects the laying and development of tissues, including temporary and permanent teeth. In this review we consider the types of intrauterine hypoxia, pathological processes that develop in the body as a whole and locally. Hard tissues of the teeth begin to be laid, develop and Mature, starting from the 6th week of intrauterine development and in the subsequent period of pregnancy corresponds to the period of formation of teeth. Manifestations of anomalies of enamel, dentin and cement are fully detected in children under 3 years of age and older. Careful collection of history of pregnancy, in conjunction with the detected anomalies of hard tissues of the teeth are able to establish the timing of intrauterine hypoxia and determine the degree of its impact on the development of teeth.

Keywords: intrauterine hypoxia, enamel, dentin, cement, hard tissues of teeth.

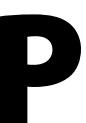
анний детский кариес является самой распространенной медицинской проблемой детей первых 3-х лет жизни. Данное заболевание является актуальным в здравоохранении всех стран мира [7, с. 44]. Шведские исследователи установили возрастание распространения раннего кариеса с возрастом: у годовалых детей распространенность составляет порядка 0,5\%, к 2-х годовалому возрасту, она возрастает до 8\%, к 3-м годам - до 28\%. В Польше распространенность кариеса у годовалых детей составила около 20,5\%. В Германии показатель колеблется до 20,3\%. В США ранний кариес - самое распространенное заболевание детского возраста среди хронических: встречается чаще астмы в 5 раз, хронического бронхита - в 14 раз. Среди населения северных штатов распространенность раннего кариеса достигала 72\%. Иранские дети подвержены раннему кариесу на 19,5-44\%. Для Голландии встречаемость заболевания составила 9,3\%. В Белоруссии (в частности, в городе Минске) встречаемость раннего кариеса у годовалых детей отмечалась на уровне 9,7\%, у 2-х летних
Макарчук Ольга Анатольевна

Врач-стоматолог, КОГБУЗ «Кировский клинический стоматологический чентр»; Ассистент, Кировский государственный медицинский университет olgamakarchuk79@mail.ru

Громова Светлана Николаевна

К.м.н., дочент, Кировский государственный медицинский университет

Аннотация. Внутриутробная гипоксия плода является достаточно распространенным явлением, которое может быть, как острым, так и хроническим состоянием. Причины развития гипоксии достаточно обширны. В свою очередь такое состояние плода влияет на закладку и развитие тканей, в том числе временных и постоянных зубов. В приведенном обзоре рассматриваются виды внутриутробной гипоксии, патологические процессы, которые развиваются как в организме в целом, так и локально. Твердые ткани зубов начинают закладываться, развиваться и созревать, начиная с 6-й недели внутриутробного развития и в последующем каждому сроку беременности соответствует свой период формирования зубов. Проявления аномалий развития эмали, дентина и цемента обнаруживаются в полной мере у детей до 3-х летнего возраста и старше. Тщательный сбор анамнеза ведения беременности, в совокупности с обнаруженными аномалиями твердых тканей зубов способны установить сроки развития внутриутробной гипоксии и определить степень ее влияния на развитие зубов.

Ключевые слова: внутриутробная гипоксия, эмаль, дентин, цемент, твердые ткани зубов.

детей - 25\% и к 2,5 годам достигала распространенности в 33\%. В среднем по России встречаемость кариеса зубов у трехлетних детей варьирует в пределах 50-60\%, в зависимости от региона [7, с. 44].

Распространенность раннего кариеса объясняется многофакторностью данного заболевания. Так в Хабаровском крае, дефицитном по фтору, распространённость кариеса зубов у детей 2-х лет в сельских районах составляет 57,2\%, в г. Хабаровске - 51,2\%; к 3-х летнему возрасту показатель возрастает до $80,5 \%$ и $77 \%$ соответственно [2].

Для развитых странах, встречаемость раннего кариеса составляет до $12 \%$. Однако для популяций с низким социально-экономическим развитием уровень заболеваемости ранним кариесом достигает 70-90\% [1, с. 44; 8].

Среди факторов, предшествующих развитию раннего детского кариеса особое место занимает гипокси- 
ческое состояние организма, начинающееся с неблагоприятного течения беременности и связанные с этим патологии [7, с. 44]. Гипоксия - понижение содержания кислорода в тканях (кровь, ткани, клетки, органы), наблюдается в условиях нарушения снабжения организма кислородом и отражает ту или иную степень кислородного голодания организма. В результате кислородного голодания в тканях возникает дисбаланс регуляторных и защитных систем организма, сопровождающийся интенсификацией свободно-радикальных процессов, усилением перекисного окисления липидов. На стадии декомпенсации защитных, антиоксидантных систем резко активируется гликолиз, падает содержание АТФ в клетках, возникает лактат-ацидоз, что может быть причиной возникновения ряда самостоятельных заболеваний. Повышение лактата на поверхности зубов в области бактериального обсеменения зубного налета, зубных бляшек - известный фактор риска кариеса. Однако меньше обсуждается значение повышенного количества лактата в слюне, возможно, в связи с тем, что у соматически здоровых детей этот фактор риска кариеса присутствует непостоянно, а риск кариеса чаще обусловлен недостаточной гигиеной полости рта, погрешностями в питании и т.д. В многочисленных работах было доказано наличие нарушений функций митохондрий и тканевой гипоксии у детей с хроническими врожденными и наследственными заболеваниями сердечно-сосудистой, центральной нервной систем, при соединительнотканных болезнях. Такие заболевания характеризуются повышением содержания молочной кислоты в крови, снижением толерантности к физической нагрузке. Внутриутробной гипоксией плода называют патологическое состояние, которое возникает при нарушении в снабжении его кислородом или неадекватной утилизации кислорода тканями и органами. Внутриутробная гипоксия является причиной развития многочисленных патологий плода и продолжает оказывать влияние на развитие организма детей после рождения. Выраженность патологических изменений во многом зависит от тяжести и длительности гипоксии плода. Внутриутробная гипоксия является первичной или предшествующей патологией. Различают антенатальную (до родовой деятельности), интранатальную (кислородная недостаточность периода родового акта) и перинатальную (после рождения). Внутриутробная гипоксия может быть обусловлена недостаточностью фетоплацентарного комплекса и болезнями самого плода. Выделяют гипоксию плода, обусловленную заболеваниями матери, сопровождающихся гипоксией и гипоксемией. Классификация по длительности протекания патологии выделяет хроническую внутриутробную гипоксию (ХВГ) плода, с длительностью периода от нескольких суток до недель, и острую гипоксию, с продолжительностью от нескольких минут до часов, чаще всего развивается во время родов.
Газообмен плода определяют следующие факторы: содержание в крови матери кислорода, углекислого газа; состояние кровотоков: маточного, маточно-плацентарного, фетоплацентарного; состояние кровообращения плода. Неполноценность одного или нескольких факторов вызывает компенсаторно-приспособительные реакции, основными из которых будут возрастание скорости кровотока плаценты, ее гиперплазия, увеличение в фетальной зоне емкости капиллярного русла плаценты, ускорение кровотока плода. Ведущей причиной острой и хронической внутриутробной гипоксии плода является недостаточность фетоплацентарного комплекса. Выделяют фетоплацентарную недостаточность первичную и вторичную. К первичной приводят аномалии развития плаценты: аномальное прикрепление, отслойка плаценты, восполение, петрификация, аномалии и патологии пуповины, возникающие до 16-й недели развития плода (имплантация, эибриогенез и плацентация). Вторичная фетоплацентарная недостаточность возникает при токсикозах беременности, экстрагенитальных заболеваниях матери (сахарный диабет, заболевания сердечно сосудистой системы, нефропатии после 16-й недели гестации на фоне сформированной плаценты. В патогенезе острой и хронической гипоксии стартовым факторон развития процесса является кислородная недостаточность, порождающая кислородное голодание тканей плода. Развитие патологического процесса будет определено фактором времени. Хроническая гипоксия характеризуется умеренной кислородной недостаточностью, и при длительном сохранении вызывает развитие в организме плода приспособительных реакций к условиям существования: усиление тканевого дыхания, повышение анаэробного гликолиза, снижение концентрации возбуждающего тканевые процессы глутамата, а также глицина, янтарной кислоты и прочих веществ. Происходит активация эритропоэза, возрастает число эритроцитов крови, увеличение её вязкости.

Гипоксия активирует функциональную активность надпочечников, повышает выработку и экскрецию их гормонов, приводящее к перераспределению крови с централизацией кровообращения. Повышенная вязкость крови, ее перераспределение изменяют микрогемодинамику плода: замедление кровотока капиллярного русла, сладжировка элементов крови с секвестрацией и повышением местного свертывающего потенциала крови, и как следствие, с локальным микротромбообразованием. Усугубляется газообмен тканей, обостряя гипоксию, нарушается васкуляризация тканей, создается ситуация их микроциркуляторной блокады, что неизбежно приводит к нарушениям в эмбриогенезе.

Нарушенный дыхательный метаболизм клеток обеспечивает транспорт ионов натрия, молекул воды внутрь клеток вместо утраченных ионов калия. Открываются 
медленные кальциевые каналы, выход свободного кальция эндоплазматического ретикулума снижается. Избыточное накопление ионов кальция клетками вызвано ослаблением активности кальциевого насоса. Повышенная активность в клетках липаз, протеаз, протеинкиназы С, усиливают процессы свободнорадикального окисления, тем самым повышая концентрацию синклетного иона кислорода, отличающегося своей токсичностью. Образовавшиеся метаболиты разрушают компоненты клеток, приводя к некрозу [3, с. 640].

Происходящие при хронической гипоксии гемодинамические, метаболические изменения вызывают на тканевом уровне два основных повреждения: геморрагический инфаркт, вследствие микротромбообразования с развитием потребления тромбоцитов, и ишемию (лейкомаляцию) [1, с. 24; 9, с. 21].

Процессы, происходящие в организме плода, сказываются на всех его клетках и тканях. Зубы развиваются вместе с развитием плода, внутриутробно. В период формирования на них влияют все те же факторы среды, что и на плод, которые отражаются на скорости формирования зубов, минерализации и сроках прорезывания. Период закладки зачатков зубов и их внутричелюстного формирования характеризуется образованием зачатков зубов, их дифференцировкой, гистогенезом и первичной минерализацией твердых тканей.

Развитие и обызыствление эмали зубов происходит в определенной последовательности: на 18-19-й недели внутриутробного развития обызыствляется 1/3 коронки и режущий край резцов, режущий край клыков и медиально-щечный бугорок первых временных больших коренных зубов; на 20-25 недели продолжается минерализация резцов, обызыствление режущего края клыков практически завершается, ускоряется минерализация щечных бугорков первых временных коренных зубов, начинается минерализация щечно-медиальных бугорков вторых временных больших коренных зубов, возникают участки обызыствления язычно-медиальных бугорков; на 26 неделе продолжается минерализация временных клыков и резцов, продолжается минерализация временных больших коренных зубов; на 32 неделе продолжается минерализация временных клыков и резцов, продолжается формирование и минерализация прочих временных зубов; к 36 неделе развития плода обызыствление поверхности временных резцов практически завершается (кроме пришеечного участка), процесс минерализации распространяется на апроксимальные поверхности первых временных моляров, повышается интенсивность минерализации временных коренных зубов. К рождению у ребенка минерализация временных зубов завершена не полностью. Развитие постоянных зубов начинается с 5-го месяца эмбриоге- неза, к 25-й неделе внутриутробного развития начинает формироваться зачаток первого постоянного большого коренного зуба, на 8-м месяце развития плода происходит закладки зачатков постоянных клыков и резцов. Закладка зачатков 16 постоянных зубов происходит в эмбриональном периоде. Обызыствление твердых тканей постоянных зубов происходит преимущественно после рождения ребенка [6, с. 256].

Влияние неблагоприятных факторов внутриутробного развития на формирование временных и постоянных зубов отмечается многими авторами [11]. Во время гипоксии, на ряду с многочисленными негативными влияниями на ткани, прежде всего нарушается их питание. В ответ на неблагоприятные условия в организме начинают включаться адаптационные механизмы [8, с. 17].

Гипоксическое состояние вызывает в организме различные приспособительные перестройки, в том числе и на генном уровне.

Три типа твердых тканей зубов, эмаль, дентин и цемент, формируются через специализированные клеточные и биохимические пути. Эти достаточно сложные механизмы контролируются генами и находятся под влиянием эпигенетических и экологических факторов $[14$, c. 15$]$.

Учеными в 2015 году были опубликованы результаты исследований по влиянию гипоксии на процессы преобразования белков эмали. Целью исследования было изучение влияния гипоксических состояний на экспрессию генов эмали и секрецию щелочной фосфатазы (ALP), лактатдегидрогеназы (LDH), цитокинов и интерлейкинов клеточной линией, происходящей из амелобластов. Клетки, полученные из мышиного амелобласта (клетки LS-8), подвергали воздействию $1 \%$ кислорода в течение 24 и 48 часов и собирали через 1, 2, 3 и 7 дней. Влияние культуры в условиях гипоксии на экспрессию генов структурного матрикса эмали и на секрецию цитокинов и интерлейкинов, а также ALP и LDH в среде для культивирования клеток рассчитывали относительно экспрессии и секреции этих факторов необработанными клетки (контроли) в каждый момент времени. Гипоксия усиливала экспрессию структурных генов эмалевого матрикса амелогенина, амелобластина и эмалелина, а также металлопротеиназы-20 эмалевой протеазы. Экспрессия индуцируемого гипоксией фактора 1-альфа и секреция некоторых факторов васкуляризации и провоспалительных факторов были повышены через 24 и 48 ч гипоксии. Активность ALP снижалась через 24 и 48 ч гипоксии, тогда как уровень LDH в среде для культивирования клеток был выше через 24 ч в условиях гипоксии по сравнению с 48 ч. Гипоксическое воздействие может нарушать контролируемую тонко настроенную экспрессию и обра- 
ботку генов эмали и способствовать секреции провоспалительных факторов.

Патологии путей развития тканей зубов могут привести к снижению количество произведенной ткани и/или низкое качество минерализация, если затронутые гены отвечают преимущественно за формирование зубных тканей, таких как амелогенин в эмали, несомненно пострадает строение зубов [12, с. 210].

Влиянии негативных факторов во время внутриутробного развития распространяется и не специфические гены, которые участвуют как в формировании зубов, так и в формировании других тканей, такие как гены ламинин-332 и коллаген тип XVII, генерализованные эффекты с участием других органы обнаруживаются в дополнение к зубным порокам.

Гипоксия, как негативный внутриутробный фактор развития твердых тканей зубов, будет проявляться в виде пороков или врожденных аномалий, на ряду с другими влияющими факторами, так как во время формирования и созревания тканей, как правило, на них воздействует совокупность факторов, выраженная в большей или меньшей степени.

В последнее время значительное внимание стали уделять роли витамина D в развитии твердых тканей зубов. Витамин D относится к группе жирорастворимых витаминов и принимает активное участие в различных метаболических процессах организма человека. Его основной функцией является регулирование баланса кальция и фосфора, которые участвуют в формировании и жизнедеятельности здоровой костной ткани.

Исследования последних нескольких лет показали гораздо более широкую роль витамина D, связанного с процессами старения, канцерогенеза, углеводного обмена, а также сопротивлением организма различным инфекциям.

Кариес является многофакторным заболеванием, его активность зависит от состава биопленки ротовой полости, углеводной диеты, состава слюны и генетических факторов. Кальций в слюне находится как в ионном, так и связанном состоянии. Считают, что около 15\% кальция связано с белками, около 30\% находится в комплексных связях с фосфатами, цитратами и др. и только 5\% кальция находится в ионном состоянии, которое является наиболее активным, обеспечивает кариес-восприимчивость и кариес-резистентность зубов [4, с. 70].

В основе минерализующей функции слюны лежат механизмы, препятствующие выходу из эмали составляющих ее компонентов и способствующие поступлению таких компонентов из слюны в эмаль. Эти механизмы и обеспечивают состояние динамического равновесия состава эмали и окружающей ее биологической жидкости - слюны, которая поддерживается на необходимом уровне благодаря равнодействию двух процессов растворения кристаллов гидроксиапатита эмали и их образования $[13$, с. 80]. Состав слюны во многом определяется витамином D. Существует доказательство того, что дефицит витамина D может приводить к гипоплазии / гипоминерализации эмали, что, в свою очередь, может приводить к повышенному риску возникновения кариеса.

Легкоферментируемые углеводы (сахара и крахмалы) являются фактором риска для развития кариеса. Процесс ферментации приводит к образованию кислоты и образованию компонентов биопленки, таких как глюканы. Недостатки питательных микроэлементов, такие как витамин C, витамин D или витамин В12, связаны с началом и прогрессированием заболеваний, однако, биологические механизмы еще недостаточно изучены. Кроме того, более высокие значения $25(\mathrm{OH})$ D связаны с меньшим числом постоянных зубов, подверженных кариесу. Витамин D индуцирует образование кателицидина, обладающего антибиотическими свойствами, и играет важную роль в уничтожении бактерий, вызывающих кариес зубов. Bion R. East описана взаимосвязь распространённости кариеса и количества солнечных лучей за год. Витамин D является активным участником формирования слюны и одним из главных факторов резистентности зубов к кариесу. Основными источниками витамина D в организме человека являются синтез в кожных покровах и пища. Дермальный синтез составляет $90 \%$, а пищевой -10\% потребности в витамине D. Провитамин D - синтезируется в коже из 7-дегидрохолестерола под воздействием ультрафиолетового света с длиной волны 270-290 нм. При высоте солнца над горизонтом выше $45^{\circ}$ (вторая половина весны и лето в умеренных широтах) необходимая для организма суточная потребность в провитамине D восполняется при 10-15 минутном облучении кожных покровов лица. Следует отметить, что при загаре в коже образуется меланин, блокирующий часть солнечного ультрафиолета, поэтому в загорелой коже синтез провитамина D требует больше времени. Загрязненность атмосферы, укороченный световой день в осенне-зимний период, одежда, укрывающая практически все тело, уменьшают выработку этого витамина и приводят к его дефициту. В современных условиях необходимо дополнительное употребление витамина D. Рекомендуемая ежедневная доза для детей $400 \mathrm{ME}$ и для взрослого населения 800 ME. Для взрослых с гиповитаминозом D рекомендована ежедневная доза витамина D от 1500 до $2000 \mathrm{ME}$ [49]. Сывороточный витамин D метаболизируется в кальцидиол [25 (OH) D)] прежде всего в печени и превращается 
в его активную форму [1,25 (ОН) 2D] (или кальцитриол) в почках. Однако превращение витамина D в $25(\mathrm{OH}) \mathrm{D}$, также, как и превращение $25(\mathrm{OH}) \mathrm{D}$ в гормональную форму - [1,25 (OH) 2D] может также осуществляться и в других тканях, что способствует биологическому действию витамина D по аутокринным и паракринным путям.

Кальцитриол транспортируется белком-переносчиком по кровяному руслу к клеткам-мишеням и связывается с рецепторами на мембранах клеточных ядер. Активированные рецепторы запускают экспрессию генов, отвечающих за синтез белков транспорта ионов кальция. С помощью такого многоступенчатого механизма витамин D регулирует уровень кальция в крови. Снижение концентрации кальция / витамина D в сыворотке вызывает секрецию паратироидного гормона (ПТГ), что влияет на активацию [25 (OH) D)]. [1,25 (OH) 2D] способствует кишечной и почечной абсорбции кальция и совместно с ПТГ активирует остеокласты, способствуя резорбции кости и освобождению кальция. Нарушение различных этапов формирования активной формы витамина D так же способно приводить к снижению его эффективности и развитию патологических состояний, в том числе и кариеса.

Аномалии эмали обычно выражаются всего несколькими способами: гипоплазия (уменьшение количества, проявляется в виде ямок, канавок, тонкой или отсутствующей эмали), гипоминерализация (сниженная минерализация проявляется как мягкая эмаль), гипоматурация (измененная прозрачность или не прозрачность, проявляющаяся как локально, так на всем зубе).

Гипоплазия эмали является результатом изменений, происходящих на стадии формирования матрицы. При гипоминерализации и гипоматурации нарушаются процессы кальцификации и минерализации, проявляющиеся в виде нарушения однородности цвета, которые происходят в последние этапы накопления минералов.

В сравнении с гипоплазией эмали, гипоминерализация и гипоматурация характеризуются нормальным количеством эмалевой матрицы. Гипоматурация характеризуется бесцветностью, непрозрачностью и ломкостью.

У детей с пороками эмали на ряду с проблемами в эстетическом виде зубов наблюдается повышенная чувствительность, риск развития кариеса, открытый прикус и плохая гигиена полости рта и передних отделов.

Аномалии дентина характеризуются в нарушении структуры и прочности ткани, проявляются опалесцирующим коричневым обесцвечиванием и, из-за нарушения поддерживающей функции, ломкости эмали, сильным стиранием зубов. Аномалии цемента по причине слабой выраженности встречаются достаточно редко, существуют в виде гипо- и гиперцементоза.

До трехлетнего возраста все пороки формирования и созревания временных зубов становятся явными. Тщательный сбор анамнеза протекания беременности, внимательное изучение патологий твердых тканей и их локализации способны установить взаимосвязи влияния внутриутробной гипоксии на твердые ткани зубов. К сожалению, до настоящего времени такие исследования либо единичны, либо отсутствуют вовсе и гипоксия, как фактор, влияющий на развитие зубов, упоминается в числе прочих негативных факторов.

\section{ЛИТЕРАТУРА}

1. Александрова Н. К. Допплерографическая оценка нарушений мозгового кровотока у новорожденных детей в раннем неонатальном периоде /Н.К. Александрова: Автореф. дис. ... канд. мед. наук. Москва, 1993.

2. Антонова А.А., Чирикова Е. Л. Распространенность и интенсивность кариеса зубов у детей раннего возраста в Хабаровском крае // Вестник Здоровье и образование в XXI веке. 2009. № 3. URL: https://cyberleninka.ru/article/n/rasprostranennost-i-intensivnost-kariesa-zubov-u-detey-rannego-vozrasta-vhabarovskom-krae

3. Барашнев Ю. И. Перинатальная неврология /Ю.И. Барашнев. М., 2001.

4. Влияние буферной системы на реминерализацию твердых тканей зуба / М. Н. Митропанова [и др.] // Проблемы стоматологии. № 2. 2013.

5. Гаврюшов В.В. Церебральная гемодинамика и теплопродукция мозга у недоношенных детей. Церебральная ишемия / В.В. Гаврюшов М.С. Ефимов, И. Ю. Галкина. //Ультразвук. диагн. в акуш., гинек. и пед. № 3. 1994.

6. Гемонов В.В., Лаврова Э. Н., Фалин Л. И. Развитие и строение органов ротовой полости и зубов М.: ГОУ вУНМЦ МЗ РФ, 2002.

7. Кариес зубов у детей раннего возраста: учеб.-метод. пособие / Н. В. Шаковец, Н. В. Ковальчук. Минск: БГМУ, 2011.

8. Кисельникова Л. П. Роль фторидов в профилактике и лечении кариеса. Круглый стол / Клиническая стоматология. № 1. 2011.

9. Кудашов Н. И. Мозговой кровоток у новорожденных с асфиксией /Н.И. Кудашов, Н. В. Иванова. // Вопр. охр. мат. и дет. № 1. 1992.

10. Ожгинина Н. В. Общие факторы риска возникновения гипоплазии эмали постоянных зубов у детей / Н. В. Ожгинина Л. П. Кисельникова И. В. Аничкова // 0бщерос. науч.-практ. конф. детских стоматологов: сб. № 3. М., 2001. 
11. Очирова Н.О., Шамас А. М. Роль протеинов на примере лизина в профилактике кариеса в стадии пятна у детей // Здоровье и образование в XXI веке. 2014. № 4. URL: https://cyberleninka.ru/article/n/rol-proteinov-na-primere-lizina-v-profilaktike-kariesa-v-stadii-pyatna-u-detey

12. Сенников С.В., Альшевская А. А., Жукова Ю. В., Беломестнова И. А., Караулов А. В., Лопатникова Ю. А. «Плотность экспрессии рецепторов к иммунорегуляторным медиаторам как модулирующий компонент биологических эффектов медиаторов на клетку» (часть 1) // Медицинская иммунология, Т. 21 , № 2. 2019.

13. Селина О. Б. Изменение минерального обмена твёрдых тканей зуба в рамках индивидуальной профилактики кариеса / 0. Б. Селина // Морфофункциональные аспекты заболеваний твёрдых тканей зубов, пародонта и слизистой оболочки полости рта: сб. науч. тр., Воронеж. 2004.

14. Цой Е. Г. Влияние хронической внутриутробной гипоксии на постнатальную адаптацию у новорожденных и методы коррекции // Мать и Дитя в Кузбассе. № 2.2004.

15. Шабалов Н. П. Неонатология. Т. 1 / Н. П. Шабалов. СПб., 1995.

(с) Макарчук Ольга Анатольевна ( olgamakarchuk79@mail.ru ), Громова Светлана Николаевна.

Журнал «Современная наука: актуальные проблемы теории и практики»

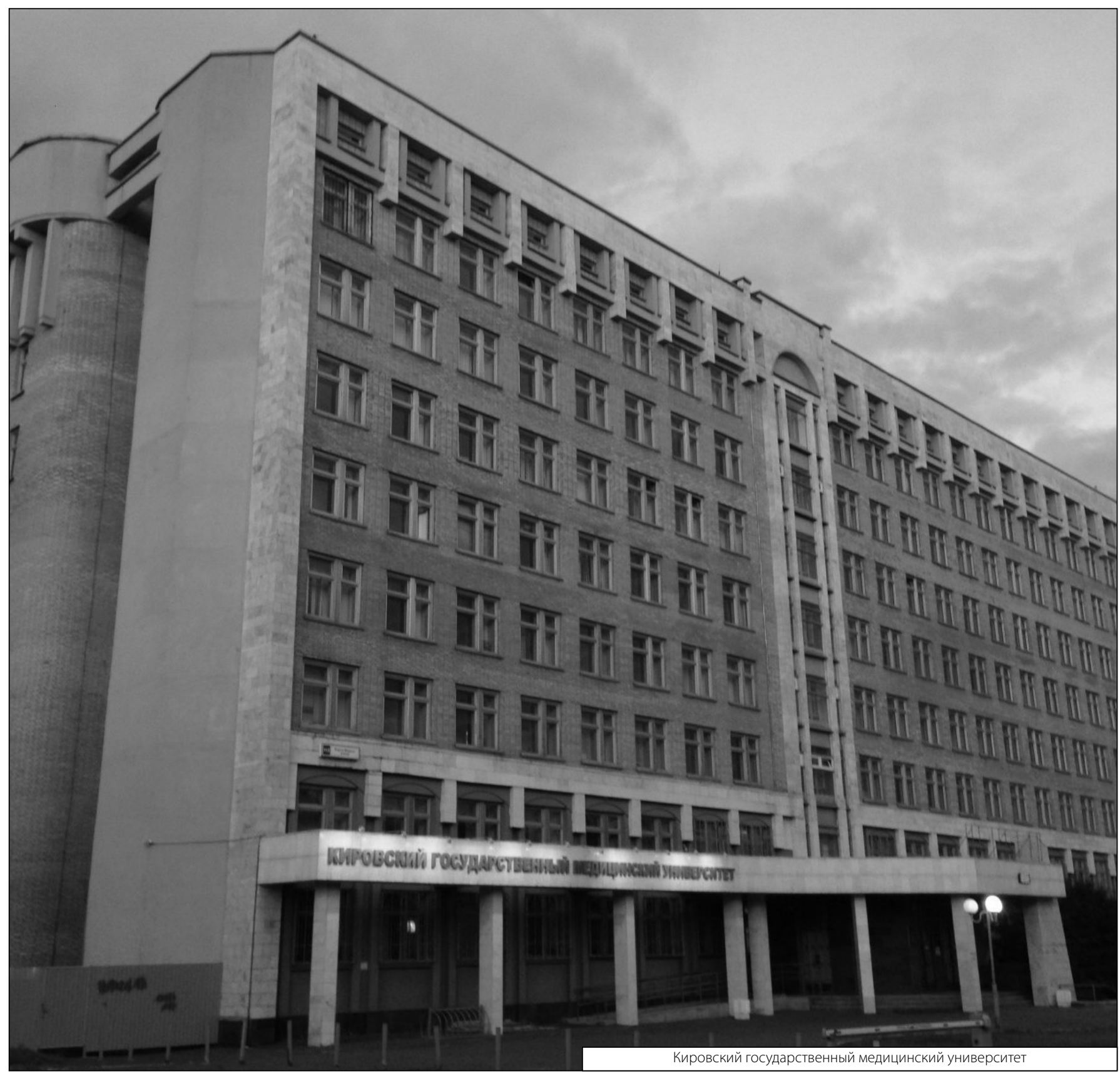

